\title{
PENGARUH PEMBERIAN BUBUR KACANG HIJAU TERHADAP PERUBAHAN \\ BERAT BADAN BALITA DENGAN STATUS GIZI KURANG \\ DI WILAYAH KERJA PUSKESMAS TAWANGHARJO \\ KABUPATEN GROBOGAN
}

\author{
Oleh; \\ Purhadi $^{1)}$, Rahmawati ${ }^{2)}$, Zaenat Joni Mustofa ${ }^{3)}$ \\ 1) Dosen Keperawatan STIKES An Nur Purwodadi, Email: asiandaru2@gmail.com \\ 2) Dosen Keperawatan STIKES An Nur Purwodadi, Email: wrahma976@ gmail.com \\ 3) Mahasiswa Keperawatan STIKES An Nur Purwodadi, Email: annurlppm@gmail.com
}

\begin{abstract}
ABSTRAK
Latar Belakang; Bubur kacang hijau merupakan makanan tambahan untuk pemulihan gizi yang diperkaya dengan vitamin dan mineral. Bubur kacang hijau memiliki kandungan protein yang lengkap sehingga dapat membantu pembentukan sel-sel tubuh dan pertumbuhan sehingga dapat meningkatkan berat badan. Penelitian ini bertujuan untuk mengetahui pengaruh pemberian bubur kacang hijau terhadap perubahan berat badan balita dengan status gizi kurang di Wilayah Kerja Puskesmas Tawangharjo Kabupaten Grobogan.
\end{abstract}

Metode; Desain penelitian yang digunakan dalam penelitian ini adalah Pra Eksperimendengan pendekatan One Group Pre Test Post Test Design.Teknik sampling yang digunakan adalah Accidental Sampling dan didapatkan 11 responden.Analisis datanya dengan bantuan computerizedmenggunakan uji paired t testdengan taraf signifikansi $95 \%$.

Hasil; Berdasarkan hasil analisa data (1) Berat badan responden sebelum diberikan bubur kacang hijau memiliki rata-rata berat badan 9054,5 gram, (2) Berat badan responden setelahdiberikan bubur kacang hijau memiliki rata-rata berat badan 9427,3 gram, (3) Ada perbedaan yang bermakna antara berat badan pre dan post pemberian bubur kacang hijau dengan nilai $t$ hitung $(3,658)>t$ tabel $(2,228)$ dan nilai pv $(0,004)<\alpha(0,05)$.

Kesimpulan -Berdasarkan hasil uji paired t test disimpulkan bahwa ada pengaruh pemberian bubur kacang hijau terhadap perubahan berat badan balita dengan status gizi kurang di Wilayah Kerja Puskesmas Tawangharjo Kabupaten Grobogan

Kata Kunci: Bubur Kacang Hijau, Balita, Status Gizi 


\title{
THE EFFECT OF GRANTING GREEN BEAN ON CHANGES IN BODY WEIGHT WITH LESS NUTRITION STATUS IN THE WORKING AREA OF TAWANGHARJO HEALTH CENTER GROBOGAN DISTRICT
}

\author{
By; \\ Purhadi $^{1)}$, Rahmawati ${ }^{2)}$, Zaenat Joni Mustofa ${ }^{3)}$ \\ 1) Lecturer of STIKES An Nur Purwodadi, Email: wrahma976@ gmail.com \\ 2) Lecturer of STIKES An Nur Purwodadi, Email: asiandaru2@gmail.com \\ 3) Student of STIKES An Nur Purwodadi, Email: annurlppm@gmail.com
}

\begin{abstract}
Background; Green bean porridgeis side dish for recovering nutrient one enriched by vitamin and mineral. Green bean porridge have fledged protein content so gets to help cell's forming body and growth so gets to increase body weight. Purpose of this research to influence green bean porridge to change under five years body weight with under nutritional status at Tawangharjo Society Health Center Region Grobogan Regency.

Method;Observational design that is utilized in this research is Pra Experiment with approaching One Group Pre Test Post TestDesign.Sampling tech that is utilized is Accidental Samplingand gotten 11 respondent. Analisis data with help computerized utilizing paired $t$ test quiz, with significant level $95 \%$.

Result; Base data analysis result (1) Body weight respondent before given by green bean porridge has average body weight 9054,5gram, (2) Body weight respondent after given by green bean porridge has average body weight 9427,3 gram, (3) Available the difference that wherewith among body weight pre and post is green bean pap application with appreciative $t$ computing $(3,658)>t$ table $(2,228)$ and pvalue $(0,004)<\alpha(0,05)$.
\end{abstract}

Conclusion; Base quiz result paired t test concluded that there is available influence green bean porridge to change under five years weight with under nutritional status at Tawangharjo Society Health Center Region Grobogan Regency.

Keyword: Granting Green Bean, Children, Nutrition Status 
PENDAHULUAN

United Nations Children's Fund (UNICEF), World Health Organization (WHO), andThe World Bank Child Malnutrition(2012), menyatakan bahwa prevalensi balita diseluruh dunia yang mengalami gizi kurang mengalami penurunan dibandingkan tahun 2011 sebesar 101 juta balita yang mengalami gizi kurang.Departemen Kesehatan RI (2014), menyatakan bahwa gizi balita pada tahun 2013 sebesar $19,6 \%$ yang terbagi masing-masing $13,9 \%$ balita mengalami gizi kurang dan 5,7\% balita mengalami gizi buruk.Berdasarkan Dinas Kesehatan Provinsi Jawa Tengah (2013), Persentase balita dengan gizi kurang (BB/U) Provinsi Jawa Tengah tahun 2012 sebesar 4,88\%.

Data dinas Kesehatan Kabupaten Grobogan (2015), menyatakan bahwa jumlah balita dengan gizi kurang sampai bulan Oktober tahun 2015 sebesar 66 responden yang tersebar diseluruh wilayah Kabupaten Grobogan. Wilayah Kerja Puskesmas Tawangharjo (2015), merupakan Puskesmas dengan jumlah balita gizi kurang terbesar dibanding dengan Wilayah Kerja Puskesmas yang lain di Kabupaten Grobogan sejumlah 11 balita.

Menurut UNICEF ada dua penyebab langsung terjadinya gizi kurang pada balita yaitu kurangnya asupan gizi dari makanan dan akibat terjadinya penyakit yang mengakibatkan infeksi. Faktor lain yang mengakibatkan terjadinya kasus gizi kurang yaitu Faktor ketidaktersediaan pangan yang bergizi dan terjangkau oleh masyarakat, perilaku dan budaya dalam pengolahan pangan dan pengasuhan anak, pengelolaan yang buruk dan perawatan kesehatan yang tidak memadai (Devi, 2010).

Penanganan gizi kurang dapat dilakukan dengan cara farmakologis atau dengan cara pemberian obat-obatan medis dan cara non farmakologis atau dengan cara pemberian makanan tambahan untuk balita. Penanganan dengan cara farmakologis yaitu dengan obat-obat pendukung untuk meningkatkan status gizi yaitu dengan kapsul Vitamin A dosis tinggi, tablet tambah darah, Mineral Mix, Taburia, obat cacing, dan antibiotik (DepKes RI, 2011).Departemen Kesehatan RI (2011), menyatakan bahwa penanganan secara non farmakologis pada anak dengan status gizi kurang diberikan makanan tambahan dan konseling.

Adina (2010), menyatakan bahwa kacang hijau memiliki kandungan protein yang lengkap sebesar 22\% sehingga dapat membantu pembentukan sel-sel tubuh dan pertumbuhan sehingga dapat meningkatkan berat badan. Selain itu kandungan lemaknya merupakan asam lemak tak jenuh. Selain protein, lemak, dan mineral seperti kalsium dan fosfor, di 
dalam kacang hijau juga terdapat vitamin $\mathrm{B}_{1}$ yang bermanfaat untuk pertumbuhan.

Bubur kacang hijau adalah jenis makanan yang dibuat dari bahan pokok kacang hijau dengan perebusan dan penambahan bumbu-bumbu sehingga didapatkan kacang hijau menjadi lunak.Bahan yang dipergunakan untuk membuat bubur kacang hijau disesuaikan dengan kebutuhan angka gizi anak sesuai umur (DepKes RI, 2011). Bubur kacang hijau untuk anak usia 6-23 bulan dibuat dari 20 gram kacang hijau, 20 gram tepung beras, 40 gram santan, dengan total energi 263 Kkal dan protein 12 gram. Bubur kacang hijau untuk anak usia 24-59 bulan dibuat dari kacang hijau 25 gram (2 sendok makan/sdm) dan santan 5 gram (1/2 sdm), dengan total energi $534 \mathrm{Kkal}$ dan protein 14 gram (DepKes RI, 2011).

\section{METODE}

Desain penelitian yang digunakan dalam penelitian ini adalah Pra Eksperiment yaitu rancangan penelitian yang sangat lemah dalam melihat pengaruh variabel independentterhadap variabel Dependent, karena pada design ini tidak ada variabel yang dikontrol demikian juga pada kelompok sampel tidak dilakukan secara random (Hidayat, 2009). Rancangan penelitian yang digunakan adalah One Group Pre Test Post Test Design, dimana penelitian ini sampel di observasi terlebih dahulu sebelum diberi perlakuan kemudian setelah diberikan perlakuan sampel tersebut di observasi kembali tanpa ada kelompok kontrol (Hidayat, 2009).

\section{HASIL}

\section{A. Karakteristik Demografi Responden}

Tabel 1; Distribusi Frekuensi Umur Responden

\begin{tabular}{lcc}
\hline \multicolumn{1}{c}{ Umur (Bulan) } & (n) & $(\%)$ \\
\hline $6-23$ & 3 & 27,3 \\
$24-59$ & 8 & 72,7 \\
Total & $\mathbf{1 1}$ & $\mathbf{1 0 0}$ \\
\hline
\end{tabular}

Tabel 2; Distribusi Frekuensi Jenis Kelamin Responden

\begin{tabular}{lcc}
\hline \multicolumn{1}{c}{ JK } & $(\mathrm{n})$ & $(\%)$ \\
\hline Laki-laki & 8 & 72,7 \\
Perempuan & 3 & 27,3 \\
Total & $\mathbf{1 1}$ & $\mathbf{1 0 0}$ \\
\hline
\end{tabular}

Tabel 3; Distribusi Frekuensi Umur Ibu

\begin{tabular}{lcc}
\hline \multicolumn{1}{c}{ Umur (Tahun) } & $(\mathrm{n})$ & $(\%)$ \\
\hline $19-25$ & 5 & 45,5 \\
$26-30$ & 3 & 27,3 \\
$31-35$ & 2 & 18,2 \\
$36-40$ & 1 & 9,1 \\
Total & $\mathbf{1 1}$ & $\mathbf{1 0 0}$ \\
\hline
\end{tabular}


Tabel 4; Distribusi Frekuensi

Pendidikan Ibu

\begin{tabular}{lcc}
\hline \multicolumn{1}{c}{ Pendidikan } & $(\mathrm{n})$ & $(\%)$ \\
\hline SD & 2 & 18,2 \\
SMP & 6 & 54,5 \\
SMA & 3 & 27,3 \\
Total & $\mathbf{1 1}$ & $\mathbf{1 0 0}$ \\
\hline
\end{tabular}

Tabel 5; Distribusi Frekuensi

Pekerjaan Ibu

\begin{tabular}{lcc}
\hline \multicolumn{1}{c}{ Pekerjaan } & $(\mathrm{n})$ & $(\%)$ \\
\hline Petani & 3 & 27,3 \\
Pedagang & 3 & 27,3 \\
IRT & 5 & 45,5 \\
Total & $\mathbf{1 1}$ & $\mathbf{1 0 0}$ \\
\hline
\end{tabular}

Tabel 6; Distribusi Frekuensi

Penghasilan Ibu

\begin{tabular}{lcc}
\hline $\begin{array}{c}\text { Penghasilan } \\
\text { (Per Bulan) }\end{array}$ & (n) & $(\%)$ \\
\hline <p 500 Ribu & 8 & 72,7 \\
Rp 500 Ribu- Satu & 3 & 27,3 \\
Juta & & \\
Total & 11 & 100 \\
\hline
\end{tabular}

B. Analisa Univariat

Tabel 7; Status Pemberian Bubur

Kacang Hijau Pada Balita

\begin{tabular}{lll}
\hline \multicolumn{1}{c}{ Status } & (n) & $(\%)$ \\
\hline Diberikan & 11 & 100 \\
Total & $\mathbf{1 1}$ & $\mathbf{1 0 0}$ \\
\hline
\end{tabular}

Tabel 8; Berat Badan Sebelum

Pemberian Bubur Kacang Hijau

\begin{tabular}{cccc}
\hline $\mathrm{n}$ & Mean & Min & Max \\
\hline 11 & 9054,5 & 6900 & 12000 \\
\hline
\end{tabular}

Tabel 9; Berat Badan Setelah

Pemberian Bubur Kacang Hijau

\begin{tabular}{cccc}
\hline $\mathrm{n}$ & Mean & Min & Max \\
\hline 11 & 9427,3 & 7200 & 12500 \\
\hline
\end{tabular}

\section{Analisa Bivariat}

Tabel 10; Pengaruh Pemberian Bubur

Kacang Hijau Terhadap Perubahan

Berat Badan Balita Dengan Status Gizi

\begin{tabular}{ccc}
\hline $\mathrm{t}$ & $\mathrm{df}$ & Sig 2 tailed \\
\hline 3,658 & 10 & 0,004 \\
\hline
\end{tabular}

\section{PEMBAHASAN}

1. Umur

Berdasarkan tabel 1 pada karakteristik umur, sebagian besar responden berusia 24-59 Bulan sebesar 8 responden $(72,7 \%)$. Menurut Supariasa, Bakri dan Fajar (2012), menjelaskan bahwa angka kejadian gizi kurang pada usia ini sering terjadi karena pada usia ini merupakan periode penyapihan. Anak yang disapih mengalami masa transisi pada pola makannya. Keadaan ini mengakibatkan asupan makanan berkurang. Masa ini disebut sebagai 
masa transisi tahun kedua (secuntrant) yaitu second year trasisional.

\section{Jenis Kelamin}

Berdasarkan tabel 2 pada karakteristik jenis kelamin, sebagian besar responden berjenis kelamin lakilaki sebesar 8 responden (72,7\%).Bila diamati lebih lanjut aktivitas fisik anak laki-laki lebih banyak daripada anak perempuan, dengan demikian kebutuhan energi lebih banyak pada anak laki-laki daripada perempuan. Hal ini didukung dengan teori yang menyatakan bahwa kebutuhan energi pada anak laki-laki adalah 112 $\mathrm{kal} / \mathrm{kgBB}$ sehari, sedangkan pada perempuan hanya 900 kalori.

\section{Umur Ibu}

Berdasarkan tabel 3 pada karakteristik umur ibu responden, sebagian besaribu responden memiliki umur 19-25 tahun sebesar 5 responden $(45,4 \%)$.faktor umur sangat mempengaruhi tingkat pengetahuan ibu tentang gizi, jadi umur ibu yang masih muda, belum memiliki banyak pengetahuan yang cukup mengenai gizi, baik ibu pada saat hamil maupun pasca melahirkan (Daryono, 2013).

\section{Pendidikan Ibu}

Berdasarkan tabel 4 pada karakteristik pendidikan ibu responden, sebagian besaribu responden memiliki pendidikan SMP sebesar 6 responden (54,5\%).Pendidikan ibu merupakan modal utama dalam menunjang ekonomi keluarga, juga berperan penyusunan makan keluarga serta pengasuhan keluarga, juga berperan dalam penyusunan makan keluarga serta pengasuhan dan perawatan anak (Mulyani, 2011).

\section{Pekerjaan Ibu}

Berdasarkan Tabel 5 pada karakteristik pekerjaan ibu responden, sebagian besaribu responden memiliki pekerjaan sebagai ibu rumah tangga sebesar 5 responden (45,5\%).Pekerjaan ibu sangat mempengaruhi proses tumbuh kembang anak. Dalam penelitian ini pekerjaan ibu sebagian besar adalah ibu rumah tangga, yang seharusnya memiliki waktu yang banyak untuk merawat anaknya. Namun, hasil penelitian ini menunjukkan masih banyak anak yang menderita gizi kurang. Hal ini dapat disebabkan karena berbagai faktor yang salah satunya adalah tingkat pendidikan.

\section{Penghasilan Ibu}

Berdasarkan tabel 6 pada karakteristik penghasilan ibu responden, sebagian besaribu 
responden memiliki penghasilan sebesar < Rp 500.000/bulan sebesar 8 responden $(72,7 \%)$.

Menurut Sihadi (2009), menyatakan bahwa penghasilan keluarga yang baik dapat menunjang tumbuh kembang anak. Hal ini dikarenakan orang tuang dengan penghasilan tinggi dapat menyediakan semua kebutuhan anak-anaknya. Rendahnya penghasilan merupakan faktor yang menyebabkan orang tidak mampu membeli pangan dalam jumlah yang diperlukan dan pangan yang mengandung zat gizi baik untuk pertumbuhan anak.

\section{Status Pemberian Bubur Kacang} Hijau

Berdasarkan tabel 7 di atas didapat semua responden di berikan bubur kacang hijau sebesar 11 responden (100\%).Kacang hijau merupakan tanaman tropis yang membutuhkan suasana panas sepanjang hidupnya.Tanaman kacang hijau dapat ditanam di daerah tropik.Berdasarkan tekstur tanah untuk penanaman kacang hijau, kacang hijau sangat baik ditanam di tanah berlempung yang banyak mengandung bahan organik, aerasi dan drainase yang baik.Secara geografis daerah di
Kecamatan Tawangharjo sangat cocok untuk ditanami kacang hijau.

\section{Berat Badan Sebelum Intervensi}

Berdasarkan tabel 8 di atas didapat berat badan responden pada sebelum diberikan bubur kacang hijau memiliki rata-rata berat badan 9054,5 gram dengan berat badan terendah terendah 6900 gram dan tertinggi 12000 gram. Keadaan Balita dengan status gizi kurang ini terus berlanjut kemungkinan penyebabnya adalah pemberian makanan tambahan pemulihan yang kurang tepat oleh ibu, yaitu jumlah/takaran makanan tambahan pemulihan yang diberikan kurang dari jumlah/takaran yang dianjurkan, hal ini karena ibu tidak pernah mengukur jumlah/takaran makanan tambahan yang diberikan, hanya asal menuang saja.Dampak yang terjadi anak akan sulit untuk mengalami pertumbuhan yang meningkat dan keadaan pertumbuhan anak dengan status gizi kurang terus berlanjut. Padahal pada usia ini, terutama pada usia 1-5 tahun merupakan usia puncak pembentukan jaringan otak pada anak yang akan berpengaruh pada perkembangan otak dimasa usia selanjutnya (Anggraini, 2011). 


\section{Berat Badan Setelah Intervensi}

Berdasarkan tabel 9 di atas didapat berat badan responden setelahdiberikan bubur kacang hijau memiliki rata-rata berat badan 9427,3 gram dengan berat badan terendah terendah 7200 gram dan tertinggi 12500 gram. Kenaikan berat badan setelah pemberian bubur kacang hijau mengindikasikan bahwa pemberian bubur kacang hijau tersebut menyebabkan adanya perbedaan pada hasil pengukuran berat badan balita.Penanganan gizi kurang dapat dilakukan dengan cara farmakologis atau dengan cara pemberian obatobatan medis dan cara non farmakologis atau dengan cara pemberian makanan tambahan untuk balita. Penanganan non farmakologis dalam penelitian ini adalah dengan bubur kacang hijau.

Bubur kacang hijau dalam penelitian ini digunakan untuk mengatasi masalah gizi kurang. Sehingga dampak gizi kurang pada balita dapat berkurang.Oleh karena itu sangat penting dilakukan penanganan berat badan pada balita dengan status gizi kurangyang salah satunya dengan penanganan non farmakologis menggunakan bubur kacang hijau. Karena kacang hijau memiliki banyak kandungan zat yang berguna untuk balita

\section{Pengaruh Pemberian Kacang Hijau dengan BB dan Status Gizi Balita}

Berdasarkan tabel 10 di atas didapatkan hasil uji beda berat badan sebelum dan sesudah diberikan bubur kacang hijau menggunakan uji Pairedttest menggunakan bantuan Computerized. Diketahui nilai t hitung $(3,658)>\mathrm{t}$ tabel $(2,228)$ dan nilai pv $(0,004)<\alpha(0,05)$. Dari hasil tersebut dapat ditarik kesimpulan bahwa terdapat perbedaan berat badan sebelum dan sesudah pemberian bubur kacang hijau.Kenaikan berat badan balita setelah diberikan intervensi kemungkinan juga bisa disebabkan ibu lebih memperhatikan dalam pemberian bubur kacang hijau disamping makanan sehari-hari.

Sebagian besar ibu responden merupakan ibu rumah tangga/tidak bekerja sebesar 45,5\%, sehingga ibu bisa lebih banyak waktu dalam memperhatikan kesehatan balita khususnya dalam hal ini adalah upaya pemberian bubur kacang hijau yang benar agar pertumbuhan berat badan balitanya tidak berada pada status gizi kurang (Suciatiningsih, 2013).Kacang hijau mengandung berbagai zat gizi dan non-gizi penting yang diperlukan 
untuk mencegah sakit, menjaga kesehatan dan kebugaran tubuh agar optimal.

Harisuddin (2012), mekanisme fisiologis kacang hijau dimulai dari mulut oleh enzim amilase masuk ke esofagus dan didorong ke dalam lambung dengan gerakan peristaltik.Di dalam lambung, makanan dicerna kembali hingga terbentuk chyme, kemudian didalam usus halus dicerna lebih lanjut dan diserap oleh tubuh dengan mengambil kandungan kacang hijau yang berupa vitamin B1 dan B2, berbagai asam amino penting, protein, serat, zat gizi mikro, mineral dan vitamin B6.

Penyerapan atau absorbsi didalam tubuh lebih cepat karena bubur kacang hijau yang diberikan lebih halus, sehingga mempercepat absorbsi makanan untuk dijadikan sumber perkembangan dan pertumbuhan. Dari teori inilah dapat disimpulkan kenaikan berat badan balita dikarenakan pemberian bubur kacang hijau

\section{SIMPULAN}

Berdasarkan hasil analisis dan pembahasan di atas, dapat ditarik simpulan bahwa (1) Berat badan responden sebelum diberikan bubur kacang hijau memiliki rata-rata berat badan 9054,5 gram. (2)
Berat badan responden setelahdiberikan bubur kacang hijau memiliki rata-rata berat badan 9427,3 gram. (3) Ada perbedaan rata-rata pre dan post pada berat badan responden pada kelompok intervensi sebesar 372,8 gram, dengan demikian ada perbedaan yang bermakna antara berat badan pre dan post pemberian bubur kacang hijau dengan nilai t hitung $(3,658)$ $>$ t tabel $(2,228)$ dan nilai pv $(0,004)<\alpha$ $(0,05)$.

\section{SARAN}

1. Diharapkan orang tua dapat menerapkan intervensi berupa bubur kacang hijau untuk diberikan kepada balita dengan status gizi kurang.

2. Hasil penelitian ini perlu diteliti lebih lanjut tentang variabel perancu lain yang dapat mempengaruhi keberhasilan pemberian bubur kacang hijau terhadap berat badan balita dengan status gizi kurang seperti pola asuh dan penyakit infeksi.

\section{DAFTAR PUSTAKA}

Agrina. (2009). Pengaruh Karakteristik Orangtua dan Lingkungan Rumah Terhadap Perkembangan Balita Di Wilayah Kerja Puskesmas Sidomulyo Rawat Inap Pekanbaru. Jakarta: Universitas Indonesia

Anggraeni dan Adriyanto. (2010). Hubungan Antara Tingkat Kesegaran Jasmani dan Status Gizi dengan Produktivitas Kerja. Jurnal 
Kesehatan Masyarakat Kesmas 5 (2) (2010) 145-150

Arikunto, Suharsimi. (2010). Prosedur Penelitian: Suatu Pendekatan Praktik. Jakarta: PT Rineka Cipta

Choirunisa.(2009). Panduan Terpenting Merawat Bayi dan Balita.Yogyakarta : Moncer Publisher

Dahlan, Sopiyudin. (2011). Statistik untuk Kedokteran dan Kesehatan. Depok: Bina Mitra Press.

Departemen Kesehatan RI. (2010). Pengertian Balita Bawah Garis Merah. Jakarta. Departemen Kesehatan Indonesia.

Departemen Kesehatan RI. (2011). Panduan Penyelenggaraan PMT Pemulihan Bagi Balita Gizi Kurang dan Ibu Hamil KEK. Jakarta: Kementerian Kesehatan RI

Departemen Kesehatan RI. (2012). Kartu Menuju Sehat model baru diluncurkan.Diakses pada 5 Maret 2013. Jakarta: Departemen Kesehatan Indonesia

Departemen Kesehatan RI. (2013). Panduan Manajemen Pemberian Taburia. Jakarta: Direktorat Jenderal Bina Gizi dan KIA Departemen Kesehatan RI

Departemen Kesehatan RI. (2014). Kebijakan Kementerian Kesehatan Dalam Penurunan AKI, AKB, dan Prevalensi Gizi Buruk. Jakarta: Direktur Jenderal Bina Gizi dan KIA Kementerian Kesehatan Republik Indonesia.

Dinas Kesehatan Provinsi Jawa Tengah. (2011). Profil Kesehatan Provinsi
Jawa Tengah Tahun 2011. Jawa Tengah: Dinkesprov Jateng

Dinas Kesehatan Provinsi Jawa Tengah. (2013). Buku Profil Kesehatan Provinsi Jawa Tengah Tahun 2012. Semarang: Dinas Kesehatan Provinsi Jawa Tengah

Dinas Kesehatan Kabupaten Grobogan. (2015). Profil Kesehatan Kabupaten Grobogan:P2PL. Grobogan: Dinkes Kab. Grobogan

Eka, Anthonie. (2011). Manfaat Kacang Hijau Untuk Kesehatan. Diperoleh dari www.document.tips/Manfaat kacang hijau untuk kesehatan_Rahasia hidup sehat.htm tanggal 25 Januari 2016

Harissuddin, Mohd. 2012. Peluang Kacang Hijau (Phaseolus Radiatus) Sebagai Diet Manula (Prosiding Seminar Nasional Pangan Fungsional Indigenous Indonesia: Potensi, Regulasi, Keamanan, Efikasi Dan Peluang Pasar. Surakarta: Universitas Sebelas Maret.

Hidayat, Alimul Azis. (2008). Pengantar Ilmu Kesehatan Anak untuk Pendidikan Kesehatan.Jakarta : Salemba Medika.

Hidayat, Alimul Azis. (2009). Metode Penelitian Kebidanan dan Tehnik Analisis Data. Jakarta: Salemba Medika

Jannah, Raudhatul. (2015). Pengaruh Pemberian Suplemen Vitamin Terhadap Perubahan Status Gizi $(B B / U)$ Balita Bawah Garis Merah (BGM) di Wilayah Kerja Puskesmas Kambat Utara Kabupaten Hulu Sungai Tengah (HST). Banjarbaru: STIKES Husada Borneo Banjarbaru 
Kumalasari, Ratih. (2011). Vitamin dan Mineral. Malang: Universitas Airlangga.

Latief, A., dkk. (2008). Diagnosi Fisis pada Anak (Edisi kedua). Jakarta: CV Sagung Seto.

Maimunah, Hasan. (2011). PAUD (Pendidikan Anak Usia Dini). Yogyakarta. DIVA Press

Masriatin, Eni. (2013). Pengaruh Pendidikan Kesehatan Tentang Pemberian Makanan Tambahan (PMT) Terhadap Kenaikan Berat Badan Balita di Posyandu Desa Jatiharjo Kecamatan Pulokulon Kabupaten Grobogan. Purwodadi: STIKES An Nur Purwodadi

Maradona.(2010). Kandungan Nutrisi pada Kacang Hijau. Jakarta: Fitness Lactamil Mama Care.

Marsaoly, Michran, Burhanudin Bahar, \& Saifuddin Sirajuddin. (2011). Pengaruh Pemberian Makanan Tambahan (Telur Rebus dan Bubur Kacang Hijau) Terhadap Status Gizi Anak Usia Sekolah. Media Gizi Masyarakat Indonesia Vol 1 No 1 Agustus (2011): 14-20.

Nursalam.(2008). Aspek Tumbuh Kembang Pada Balita. Jakarta. EGC.

Nurwati, N., R. Nizar, L. Siswati.(2012). Alokasi Pendapatan dan Pola Konsumsi Pangan Rumah Tangga di Kecamatan Rumbai Kota Pekanbaru. Pekanbaru: Fakultas PertanianUniversitas Lancang Kuning.

Purwono \& R. Hartono.(2012). Kacang Hijau. Jakarta: Penebar Swadaya

Roseliana. 2013. Gambaran Pengetahuan Ibu Tentang Kartu Menuju Sehat
(KMS) Balita di Puskesmas Ciputat Timur Kota Tanggerang Selatan. Jakarta : UIN Syarif Hidayatullah

Saryono.(2009). Metodologi Penelitian Kesehatan: Penuntun Praktis Bagi Pemula. Yogjakarta: Mitra Cendekia Press.

Siswanto, H. (2010). Pendidikan Kesehatan Anak Usia Dini. Yogyakarta: Pustaka Rihama.

Suciatiningsih, Ilya Krisnana, dan Kristiawati. 2013. Peningkatan Berat Badan Pada Bayi (6-23 Bulan) Melalui Infant Exercise. Malang: Universitas Airlangga

Sugiyono.(2010). Statistika untuk Penelitian. Bandung: CV Alfabeta

Sulistyawati.(2011). Pengaruh Pemberian Diet Formula 75 dan 100 Terhadap Berat Badan Balita Gizi Buruk Rawat Jalan di Wilayah Kerja Puskesmas Pancoran Mas Kota Depok. Jakarta: Universitas Indonesia

Suparyanto.(2011). Konsep Balita. Diperoleh dari http://drsuparyanto.blogspot.co.id/2011/03/k onsep-balita.html?m=1 diperoleh tanggal 15 Januari 2016

Surtinah, Seprita Lidar, Neng Susi, \& Enny Mutryarny.(2012). Sosialisasi Manfaat Sari Kacang Hijau Di Posyandu RW 3 Kelurahan Umbansari Kecamatan Rumbai Kota Pekanbaru. Pekanbaru: Universitas Lancang Kuning.

Teguh, A.(2010). Khasiat dan Kandungan Gizi Kacang Hijau. Diperolehdari http://www.wikipedia.org.Pada tanggal 15 Oktober 2015. 
United Nations

Children's Fund(UNICEF), WHO, and The World Bank Child Malnutrition. (2012). Levels \& Trend Child Malnutrition. USA: UNICEF, WHO, and The World Bank Child Malnutrition

United Nations Children's Fund(UNICEF), WHO, and The
World Bank Child Malnutrition. (2013). Estimates For2012 And Launch Of Interactive Data Dasboards. USA: UNICEF, WHO, and The World Bank Child Malnutrition

World Health Organization (WHO). (2010). The Spectrum of Malnutrition. USA: WHO 